\title{
Human prostate supports more efficient replication of HIV-I R5 than $X 4$ strains ex vivo
}

\author{
Anna Le Tortorec ${ }^{1,2}$, Anne-Pascale Satie ${ }^{1,2}$, Hélène Denis ${ }^{1,2}$, Nathalie Rioux- \\ Leclercq $^{4,5}$, Laurence Havard ${ }^{3}$, Annick Ruffault ${ }^{3}$, Bernard Jégou ${ }^{1,2}$ and \\ Nathalie Dejucq-Rainsford*1,2
}

Address: ${ }^{1}$ Inserm, U625, Rennes, France, ${ }^{2}$ Univ Rennes I, Campus de Beaulieu, IFR-140, GERHM, Rennes, F-35042, France, ${ }^{3}$ Unité de rétrovirologie, CHU Pontchaillou, Rennes, France, ${ }^{4}$ Service d'anatomie et cytologie pathologiques, CHU Pontchaillou, Rennes, France and ${ }^{5} \mathrm{CNRS/}$ UMR6061, IFR140, Faculté de Médecine, Université de Rennes1, France

Email: Anna Le Tortorec - anna.le_tortorec@kcl.ac.uk; Anne-Pascale Satie - anne-pascale.satie@univ-rennes1.fr;

Hélène Denis - helenebruneau@hotmail.com; Nathalie Rioux-Leclercq - nathalie.rioux@chu-rennes.fr; Laurence Havard - annick.ruffault@univrennes1.fr; Annick Ruffault - annick.ruffault@univ-rennes1.fr; Bernard Jégou - bernard.jegou@univ-rennes1.fr; Nathalie Dejucq-

Rainsford* - Nathalie.dejucq-rainsford@rennes.inserm.fr

* Corresponding author

Published: 3I December 2008

Retrovirology 2008, 5:119 doi:10.1186/1742-4690-5-119
Received: 20 November 2008

Accepted: 31 December 2008

This article is available from: http://www.retrovirology.com/content/5/1/119

(C) 2008 Le Tortorec et al; licensee BioMed Central Ltd.

This is an Open Access article distributed under the terms of the Creative Commons Attribution License (http://creativecommons.org/licenses/by/2.0), which permits unrestricted use, distribution, and reproduction in any medium, provided the original work is properly cited.

\begin{abstract}
Background: In order to determine whether human prostate can be productively infected by HIV-I strains with different tropism, and thus represent a potential source of HIV in semen, an organotypic culture of prostate from men undergoing prostatic adenomectomy for benign prostate hypertrophy (BPH) was developed. The presence of potential HIV target cells in prostate tissues was investigated using immunohistochemistry. The infection of prostate explants following exposures with HIV-I R5, R5X4 and X4 strains was analyzed through the measure of RT activity in culture supernatants, the quantification of HIV DNA in the explants and the detection of HIV RNA+ cells in situ.
\end{abstract}

Results: The overall prostate characteristics were retained for $2^{1 / 2}$ weeks in culture. Numerous potential HIV-I target cells were detected in the prostate stroma. Whilst HIV-I R5 SFI62 $_{\text {strain }}$ consistently productively infected prostatic $T$ lymphocytes and macrophages, the prototypic $X 4_{\text {IIIB }}$ strain and a primary R5X4 strain showed less efficient replication in this organ.

Conclusion: The BPH prostate is a site of HIV-I R5 replication that could contribute virus to semen. A limited spreading of HIV-I X4 and R5X4 in this organ could participate to the preferential sexual transmission of HIV-I R5 strains.

\section{Background}

Although semen represents the foremost vector of HIV-1 dissemination worldwide, the origin of the infected leukocytes and free viral particles contaminating the seminal plasma is still unclear. Semen represents a viral compartment distinct from the blood (reviewed in [1]), strongly suggesting the existence of productive sources within the male genital tract. The male reproductive tract could con- 
stitute a sanctuary for HIV-1 replication, since HIV-1 can persist in the semen of seropositive men on highly active antiretroviral therapy (HAART) in the absence of detectable levels of viral RNA in plasma [2-7]. Knowing the sources contributing virus to semen is essential to promoting the design of therapies aimed at eradicating virus from semen.

Semen is composed of secretions and cells from the testes, epididymides, prostate, seminal vesicles and urethral glands. Earlier studies showed that vasectomy has little impact on seminal shedding of HIV-1 [8-11], indicating that testes and epididymides are not the main sources of viral load in semen. The prostate could represent an important source of virus in the semen, since prostate secretions constitute $30 \%$ of the seminal fluid and the human prostate is frequently inflammed, encompassing leukocytic infiltrates that may represent target cells for HIV infection (for a review, [12]). We recently demonstrated that the prostate of asymptomatic macaques is productively infected by SIV and displays higher level of infection than the testes and the epididymides [13]. In human, indirect evidence suggests that the prostate is infected and constitutes an early viral reservoir. Thus, prostatic massages performed on asymptomatic HIV-1+ men with no detectable seminal viral load induce the release of virus in the semen [14], and the expressed prostatic secretions from HIV-1+ men with or without ART are consistently positive for HIV RNA [15]. However, for obvious clinical and ethical reasons, in-depth investigations of HIV infection of the prostate of HIV+ asymptomatic men have never been performed.

In vitro studies using a number of different human organs, including the testis [16], have proved invaluable for improving the understanding of HIV pathogenesis. To test the hypothesis that the human prostate represents a source of virus in semen, we used an organotypic culture of prostate tissue obtained from men with benign prostate hypertrophy (BPH), a common non-malignant pathology, to assess whether the resident immune cells or other cell types present in this organ are susceptible to infection by HIV-1 strains with various co-receptor requirements.

\section{Methods}

\section{Chemicals and reagents}

The following reagents were used: DMEM, RPMI 1640 (Gibco BRL, Life Technologies, Cergy-Pontoise, France), fetal calf serum (FCS), sodium pyruvate (Eurobio, Courtaboeuf, France), glutamine (Gibco BRL), insulin, vitamin A, vitamin $\mathrm{C}$, vitamin $\mathrm{E}$, dihydrotestosterone, phytohemagglutinin (Sigma, Sigma-Aldrich Corp., St. Quentin Fallavier, France), penicillin-streptomycin (Eurobio) and interleukin-2 (Boehringer-Mannheim, Germany).

\section{Antibodies, plasmids and cell lines}

The following mouse monoclonal antibodies against human proteins and matching isotype controls were used: anti-CD68 (clone KP1), -CD3 (clone F.7.2.38) $(7 \mu \mathrm{g} / \mathrm{ml}$ ), - HLA-DR (clone TAL.1B5), -Ki-67 (clone MIB-1) (DAKO, Trappes, France), -PSA (clones ER-PR8 and PA05 from Neomarkers), and -CD4 (clone 1F6, Novocastra, Newcastle, UK) with mouse IgG1 (DAKO), anti-CCR5 (clone 45523) and IgG2b (R\&D Systems, Minneapolis, MN), anti-CXCR4 (clone 12G5; Dr. J. Hoxie, NIBSC Centralized Facility for AIDS Reagent, UK), - alpha-smooth muscle actin (clone 1A4, DAKO), - p63 (clone 4A4, DAKO) and IgG2a (R\&D Systems).

The pNL4.3 plasmid was provided by F. Mamano (Inserm U552, Paris, France). Human T-Lymphoblastoïd C8166 cell line was obtained from the NIBSC Centralized Facility for AIDS Reagent.

\section{Viral stocks}

HIV-1 clade B R5 $5_{\mathrm{SF} 162}, \mathrm{X} 4_{\text {IIIB }}$ strains and R5X4 $4_{92 \mathrm{US723}}$ primary isolate (ARP1039.3) were obtained from the NIBSC Centralized Facility for AIDS Reagent and expanded in activated human PBMCs $\left(\mathrm{R}_{\mathrm{SF} 162}, \mathrm{R} 5 \mathrm{X} 4_{92 \mathrm{US723}}, \mathrm{X} 4_{\text {IIIB }}\right)$ or in C8166 cells (X4 $4_{\text {IIIB }}$ ) to provide viral stocks of $40000 \mathrm{pg} /$ $\mathrm{ml}$ for R5 $5_{\mathrm{SF} 162}, 40000 \mathrm{pg} / \mathrm{ml}$ (PBMCs) to $60000 \mathrm{pg} / \mathrm{ml}$ (C8166) for X $4_{\text {IIIB }}$ and $10000 \mathrm{pg} / \mathrm{ml}$ for $\mathrm{R} 5 \mathrm{X} 4_{92 \mathrm{US723}}$ as determined by RT activity assay.

\section{Organotypic culture of human prostate explants}

The protocol was approved by the local ethics committee of Rennes, and informed consent was obtained from the donors. Prostates tissues were obtained at the Rennes University Hospital from healthy, HIV-1 seronegative patients (age range 50-55) who underwent prostatic adenomectomy for $\mathrm{BPH}$. Immediately following surgery, prostate tissues were placed at $4{ }^{\circ} \mathrm{C}$ in fresh medium and processed within one hour. The benign pathological status was confirmed by histological examination. Prostate tissue from the transition zone and the central zone was dissected into $3-\mathrm{mm}^{3}$ fragments, and two explants were transferred onto a polyethylene terephtalate (PET) insert in a well of a 12well tissue culture plate (Falcon Labware; Becton-Dickinson and Co., Lincoln Park, NJ) containing $1 \mathrm{ml}$ of media (DMEM supplemented with antibiotics, 10\% FCS, 1 $\mathrm{mmol} / \mathrm{L}$ sodium pyruvate, $1 \mathrm{mmol} / \mathrm{L}$ glutamine, $100 \mathrm{ng} /$ $\mathrm{ml}$ vitamin A, $200 \mathrm{ng} / \mathrm{ml}$ vitamin $\mathrm{E}, 50 \mathrm{ng} / \mathrm{ml}$ vitamin $\mathrm{C}$, $0.5 \mu \mathrm{g} / \mathrm{ml}$ insulin, and $800 \mathrm{ng} / \mathrm{ml} 5 \alpha$-dyhydrotestosterone). Each experimental condition was made up of two wells of two biopsies per well. The culture was established for 17 days in a humidified atmosphere containing 5\% $\mathrm{CO} 2$ at $37^{\circ} \mathrm{C}$, medium was changed every 2 days, and stored frozen at $-80^{\circ} \mathrm{C}$. Every 2 days, prostate explants were either fixed in neutral buffered $4 \%$ formaldehyde or frozen and stored at $-80^{\circ} \mathrm{C}$. 


\section{Immunohistochemistry and cell count}

Immunohistochemistry using avidin-biotin peroxidase complex technique was performed on formaldehydefixed, paraffin-embedded tissues as previously described [16]. No staining was ever observed with isotype control antibodies or control serum. Stained positive cells were counted in the total surface of the tissue section in a minimum of three independent cultures using the Cast Grid software (Olympus).

\section{Infection of prostate explants}

Immediately after dissection, two fragments of human prostate tissue ( $3 \mathrm{~mm}^{3}$ each) were immersed in either $200 \mu \mathrm{l}$ (for R5 $5_{\mathrm{SF} 162}$ and X $4_{\text {IIIB }}$ ) or $600 \mu \mathrm{l}$ (for R5X4 $4_{92 \mathrm{US723}}$ ) of cell-free viral supernatant for 3 hours at $37^{\circ} \mathrm{C}$ and then thoroughly rinsed three times in PBS. The explants were placed in culture as described above, and the culture medium replaced and collected every 2 days throughout the culture and stored at $-80^{\circ} \mathrm{C}$ for RT and viral infectivity assays.

\section{Reverse Transcriptase (RT) activity assay}

Frozen culture supernatants were assayed in duplicates for RT activity using the Lenti-RT activity assay (Cavidi Tech, Uppsala, Sweden) according to the manufacturer's instructions. Unknown values were obtained from the standard curve interpolation and were expressed as $\mathrm{pg} / \mathrm{ml}$ of RT.

\section{Simultaneous in situ hybridization and immunohistochemical staining}

Identification of cell types expressing HIV-1 RNA was performed by combining radioactive in situ hybridization for HIV-1 gag and immunohistochemical staining for cell markers, as previously described [16]. The specificity of the hybridization signal was systematically checked by hybridizing sense probes on parallel sections and antisense probes on uninfected prostate tissue.

\section{Viral infectivity assay}

$500 \mu \mathrm{l}$ of prostate culture supernatants collected at day 17 after infection, or $500 \mu \mathrm{l}$ of viral stock maintained at $37^{\circ} \mathrm{C}$ for 17 days (used here as a negative control) were ultracentrifuged for 1 hour at $17000 \mathrm{rpm}$. Supernatants were discarded and pellets dissolved in $500 \mu \mathrm{l}$ of RPMI 1640, which was added to $4 \times 10^{6}$ phytohemagglutinin-activated PBMCs for 3 hours at $37^{\circ} \mathrm{C}$. After a 10 -minute centrifugation at $1200 \mathrm{rpm}, \mathrm{PBMCs}$ were re-suspended in 2 ml of RPMI 1640 supplemented with 5\% interleukin-2 and maintained at $37^{\circ} \mathrm{C}$ for 14 days. Culture medium was changed every 3 days and stored frozen at $-80^{\circ} \mathrm{C}$ for subsequent RT assay.

Measurement of HIV-I DNA using TaqMan real-time PCR Total DNA was extracted using the QIAamp DNA Mini Kit (Qiagen) according to the manufacturer's instructions.
Quantitative real time PCR was performed on $250 \mathrm{ng}$ DNA as previously described, using primers and probes for HIV-1 LTR and albumin gene amplification [16,17]. For each donor and each time point, two separate pieces of tissue were analyzed in duplicate. Results were expressed as copy number of Log10 HIV DNA copy number/million cells.

\section{Statistics}

All values are the mean \pm SEM. The significance of the differences between values was evaluated using Dunnett test. This test controls the Type I experiment-wise error for comparisons of all samples against a control (described in the figure legends). A value of $\mathrm{p}<0.05$ was considered statistically significant.

\section{Results \\ Characterization of human prostate in organotypic culture}

The morphology and expression of prostatic cell markers were compared in prostate explants before culture and throughout the culture period. Histological examination of prostatic fragments revealed that the tissue architecture was maintained during the 17 day culture period (Fig. 1A versus F). Staining for $\alpha$ smooth actin before culturing revealed the presence of numerous smooth muscle cells and myofibroblasts as well as unstained stromal cells (i.e. fibroblasts, leukocytes and endothelial cells). After 17 days of culture, whilst the same global profile of staining was observed, a diminution of the number of stromal cells, mainly in the centre of the explants was noticed (Fig. $1 \mathrm{~B}$ versus G). Epithelial basal cells (p63+, PSA-) surrounding the acini were maintained throughout the culture (Fig. $1 \mathrm{C}, \mathrm{H})$ and were seen encapsulating the explants from day 4 of culture (data not shown). Luminal columnar epithelial cells (PSA+, p63-) maintained their ability to produce PSA for up to 4 days of culture (Fig. 1D versus I). After 8 days of culture, PSA expression in these cells became undetectable, although PSA positive secretions were still found in acini lumen by day 17 (Fig. 1J). In the explants before and after culture, only a small cell number was proliferating, as shown by the detection of Ki67 (Fig. 1E, K).

\section{Detection and quantification of potential HIV-I target cells in human BPH prostate}

Cells staining positive for the activated immune cells marker HLA-DR (Fig. 2A), the T lymphocyte marker CD3 (Fig. 2C), the Thelper lymphocyte marker CD4 (Fig. 2B), and the myeloid cell marker CD68 (Fig. 2D) were found within the stroma of fixed prostate tissues from all donors before culture, either scattered or in periglandular foci (mainly composed of HLA-DR+, CD3+ and CD4+cells; serial sections, Fig. 2A, B). These immune cells were also occasionally found as isolated cells inserted within the epithelium of the glands (arrows, Fig. 2). The HIV coreceptors CCR5 (Fig. 2E) and CXCR4 (Fig. 2F) were 

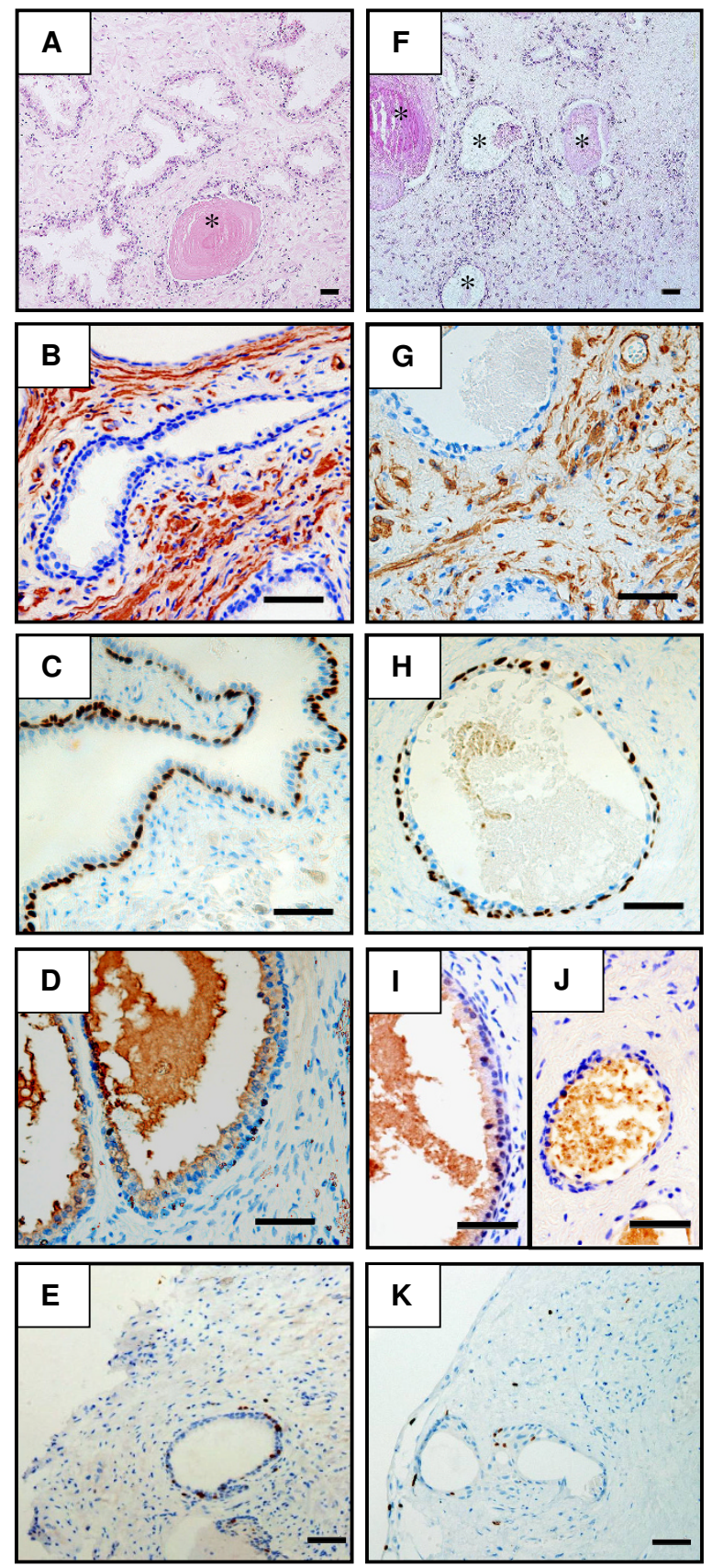

\section{Figure I}

Characterization of human prostate in organotypic culture. Paraformaldehyde-fixed paraffin sections were examined morphologically and immunostained for several prostatic cell markers before culture (A-E) and after 4 days (I) or 17 days (F-H, $\mathrm{J}, \mathrm{K}$ ) of culture. (A, F): a mix of normal and hyperplasic glands (identified by stars) were observed in the tissue sections before and after 17 days of culture. The overall morphology of the organ was preserved after 17 days of culture despite a loss of stromal cells in some areas $(F)$. The markers used for the characterization of prostatic cell types were: $-\alpha$ smooth actin for smooth muscle and myofibroblastic stromal cells (B, G); - p63 for basal epithelial cells (C, H); - PSA for secretory luminal epithelial cells (D, I, J); - Ki67 for proliferating cells (E, K). The results are representative of a minimum of three independent cultures performed on prostates collected from different donors. Scale bars $=50 \mu \mathrm{m}$. 

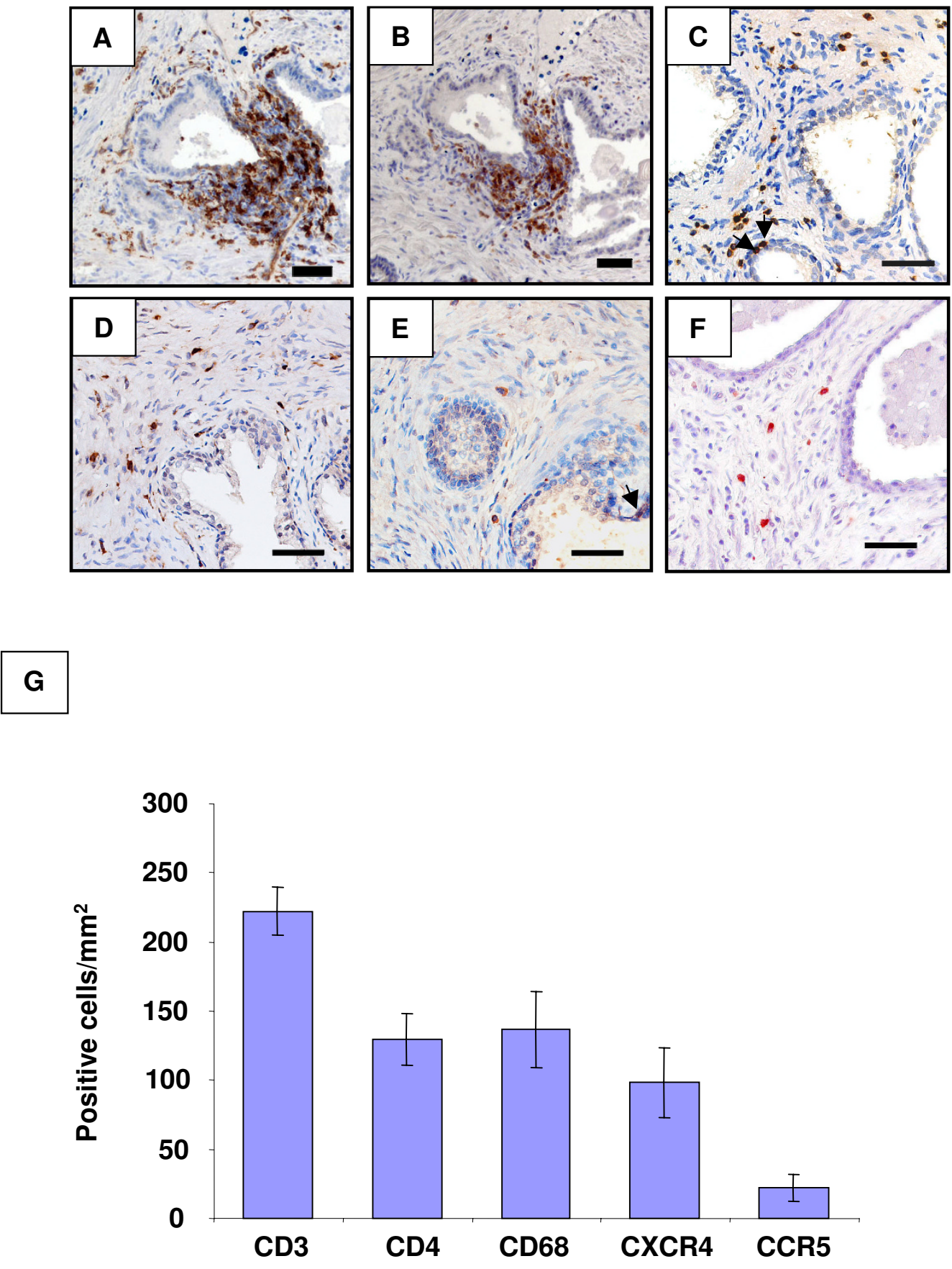

Figure 2

Presence of potential HIV target cells in the human prostate. Immunohistochemistry on uninfected prostate sections before culture showed the presence of periglandular foci of HLA-DR+ $(A)$ and CD4+ cells (B, serial section with $A)$ as well as scattered stromal cells staining positive for HLA-DR (A), CD4 (B), CD3 (C), CD68 (D), CCR5 (E) and CXCR4 (F). The arrows point out immune cells inserted within the epithelium-Scale bars $=50 \mu \mathrm{m} ;(\mathrm{G})$ : the respective proportions of $C D 3, C D 4$, CD68, CXCR4 and CCR5+ cells per surface unit were evaluated on whole prostate sections from a minimum of 3 donors whose explants were subsequently exposed to HIV-I strains. 
detected on cells with immune cell type morphology. Quantitative immunohistochemistry indicated that CD3+ T lymphocytes consistently out-numbered CD68+ myeloid cells whilst CXCR4+ cells were more frequently encountered than CCR5+ cells in the prostatic tissue sections examined (Fig. 2G). Staining for all these cell populations was still observed at the end of the culturing period (data not shown).

\section{Infection of prostate explants with R5, R5X4 and X4 HIV- I strains}

Following the incubation of $\mathrm{R} 5_{\mathrm{SF} 162}$ with prostate explants from 3 donors, a significant increase in RT activity was consistently observed at day 17 of culturing (Fig. 3A). Viral particles obtained by centrifugation of prostate supernatants collected at the end of the culturing time productively infected activated PBMCs (Fig. 3B), whilst an inoculum of the SF162 viral stock left in the culture medium for 17 days at $37^{\circ} \mathrm{C}$ did not trigger PBMCs infection, indicating that infection was caused by newly released virions and not by the potential remains of the initial inoculum. Exposure of prostate tissues to R5X4 $4_{9245723}$ primary isolate induced lower RT activity increases than $\mathrm{R}_{\mathrm{SF} 162}$, and the RT level was highly variable depending on the patient (Fig. 3C). Accordingly, highly variable levels of productive infection of PBMCs by R5X4-infected prostate culture supernatants were observed (Fig. 3D). In contrast, in supernatants of matched blocks of prostate tissues (same patients) and in prostate tissues from two additional patients exposed to $\mathrm{X} 4_{\text {ІІІв }}$ grown in C8166, no or extremely low increases in RT activity were detected during the 17 day-culture period (Fig. 3E). The supernatants from $\mathrm{X}_{\mathrm{IIIB}}$-exposed prostate cultures triggered either no or very low infection of PBMCs (Fig. 3F). Similar results were obtained using X $4_{\text {IIIB }}$ stocks grown in PBMCs (data not shown).

The quantity of HIV DNA within the prostate explants exposed to either R $5_{\mathrm{SF} 162}$ or $\mathrm{X} 4_{\text {IIIB }}$ was measured using QPCR (Fig. 4). HIV-1 DNA level rose from 7 days onwards post-exposure to $\mathrm{R}_{\mathrm{SF} 162}$ (on average, $+\approx 0.7 \mathrm{Log}$ at day 13 and $+\approx 2.4$ Log at day 17 ), demonstrating productive infection. In contrast, no increase of HIV DNA was observed in prostate explants exposed to $\mathrm{X} 4_{\text {IIIB }}$ between day 7 and 13 . Although relatively modest (on average $\approx$ $0.6 \mathrm{Log}$ ), an increase was observed at the end of the culturing period (Fig. 4), indicating a low level of $\mathrm{X}_{\text {IIIB }}$ replication. Of note, the overall morphology and the cellular expression of PSA, p63, $\alpha$ smooth actin and Ki67 of the infected explants at day 4,11 and 17 of culture was similar to those of uninfected explants (data not shown).

\section{Localization and characterization of HIV-I RNA+ cells in BPH prostate explants}

Infected cells were localized within the explants by in situ hybridization for HIV-1 gag mRNA and characterized by combined immunohistochemistry for cell markers (Fig. 5). In all explants exposed to $\mathrm{R} 5_{\mathrm{SF} 162}$, and in those exposed to R5X4 $4_{92 \mathrm{US723}}$, mostly isolated and occasional groups of HIV-1 RNA positive cells were detected in the prostatic stroma (Fig. 5A, B). A few HIV+ cells were also observed close to, or inserted within, the prostatic epithelium (Fig. 5C). HIV+ cells co-localized with CD3 (Fig. 5B, $\mathrm{B}^{\prime}, \mathrm{C}, \mathrm{C}^{\prime}$ ) and, more rarely, with CD68 (Fig. 5A, A'). Scarcely distributed CD3+HIV-1+ cells were detected in the stroma of $\mathrm{X}_{\mathrm{IIIB}}$-exposed prostate explants with low RT activity (data not shown).

\section{Discussion}

Whilst few previous studies have detected HIV-1 within the morphologically abnormal prostate from AIDS deceased men [11,18-20], the susceptibility to HIV-1 infection of the prostate from asymptomatic men has not been thoroughly explored. Here, we used an organotypic culture of prostate tissue from HIV-negative men with benign prostatic hypertophy (BPH) to investigate infection by R5, R5X4 and X4 HIV-1 strains and to determine the nature of the target cells within this organ.

$\mathrm{BPH}$ is an extremely common disease (for a review, [21]). Starting from 35 years of age, its frequency increases with age, and it affects 50 to $75 \%$ of men over 50 years old. It leads to an enlarged prostate which although benign and non-malignant may necessitate surgery to eliminate discomfort. Most $\mathrm{BPH}$ lesions develop in the transition and central zones of the prostate and are composed of epithelial, muscular and/or stromal hyperplasia. Inflammatory infiltrates are often present in and around the glandular or fibromuscular BPH nodules [12]. In our BPH tissues, T lymphocytes (mean of 220 cells $/ \mathrm{mm}^{2}$ ), mainly stromal $\mathrm{CD} 4+$, were more numerous than CD68+ myeloid cells and were found either scattered or in foci. These results are in agreement with previous qualitative and quantitative studies on immune cell populations within BPH prostates, showing the predominance of $\mathrm{T}$ lymphocytes (mean of 195 cells/ $\mathrm{mm}^{2}$, mainly stromal memory CD4+T cells and a few intraepithelial CD8+ cells) over macrophages and B cells [22-24]. Normal prostate (i.e. from asymptomatic prostate disease-free men) contains scattered stromal and intraepithelial T and B lymphocytes, macrophages and mast cells [23], but also frequently displays focal accumulation of CD4+T lymphocytes in the stroma [25-27]. As a matter of fact, most adult prostate tissues, with or without prostatic pathology, contain various extent of inflammatory infiltrates, most commonly composed of a majority of stromal $\mathrm{T}$ cells (reviewed in $[12,28]$. The source of intraprostatic inflammation is often unknown but might be caused by dietary factors, hormonal exposure variations, infection, or cell injury (for a review [12]). 


\section{Prostate explants}

A

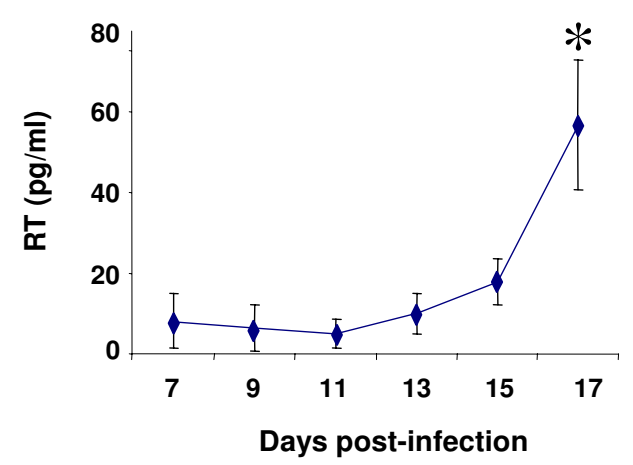

C

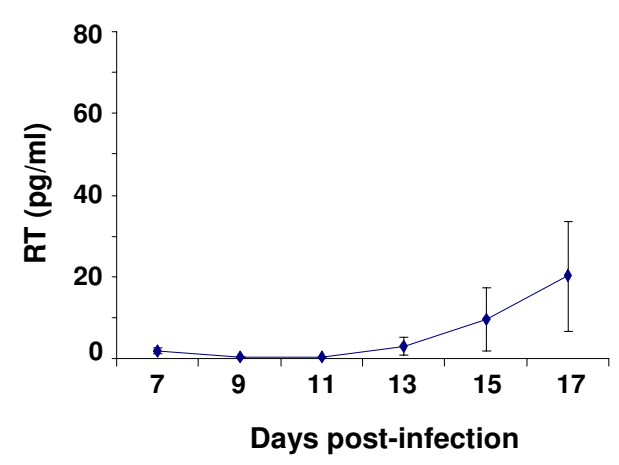

E

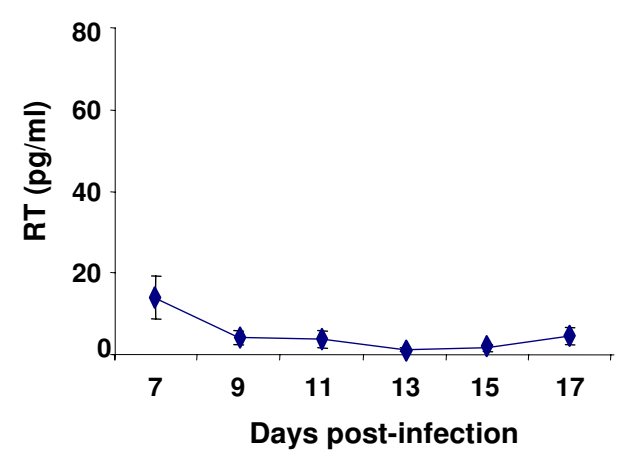

B
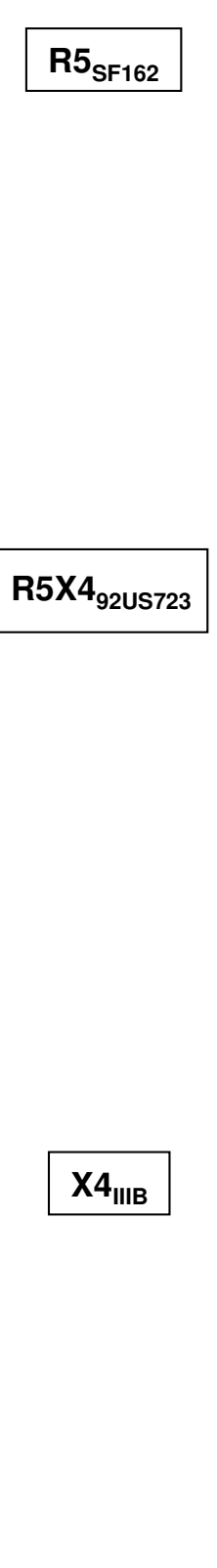

\section{PBMCs}

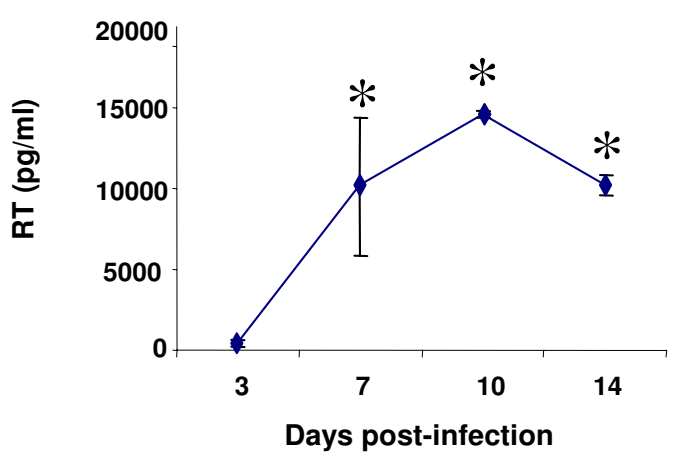

D

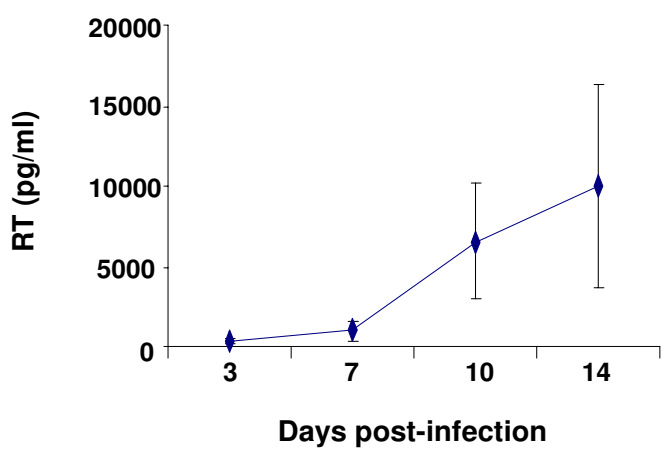

F

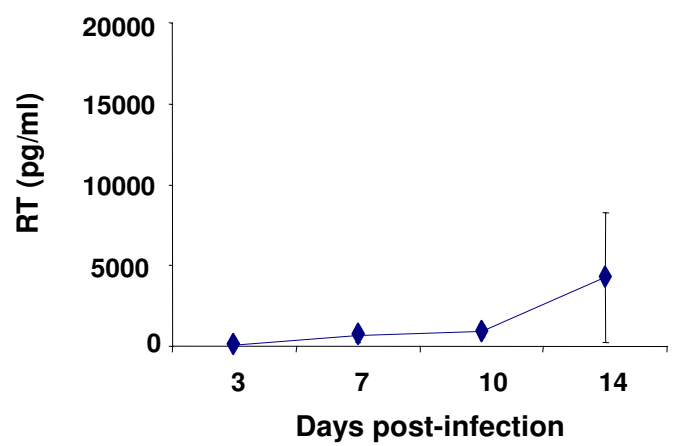

\section{Figure 3}

HIV-I R5, R5X4 and X4 infection of human prostate in organotypic culture. RT activity was measured in supernatants of human prostate explants exposed to HIV-I R5 $5_{\text {SFI62 }}\left(n=3\right.$ donors) (A), R5X4 $4_{92 U 5723}\left(n=3\right.$ donors) (C), or X $4_{\text {IIIB }}(n=5$ donors) (E); and in supernatants of activated PBMCs exposed to day 17 supernatants of prostate explant cultures exposed to $R 5_{\text {SFI62 }}(n=3)(B), R 5 X 4_{92 U S 723}(n=3)(D)$ or X4 $4_{I I B}(n=5)(F)$. RT activity was never detected in the supernatants of PBMCs infected with an inoculum of the respective viral stocks maintained at $37^{\circ} \mathrm{C}$ in medium for 17 days. Each dot represents the mean \pm SEM of three to five independent cultures (Dunnett test; $*, P<0.05$; control: day 7 ). 


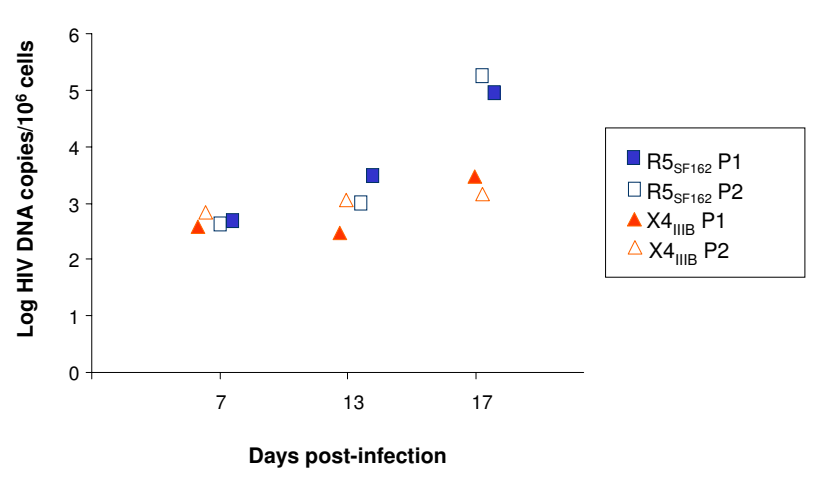

Figure 4

Accumulation of HIV-I DNA in prostate explants following exposure to either $R 5_{\mathrm{SF} \mid 62}$ or $X 4_{\text {IIIB }}$, as assayed for LTR DNA by quantitative real time PCR. Each dot represents the mean value of 2 paired explants (each tested in duplicate PCR) from one individual. For each virus strain, prostate explants from 2 patients were analyzed.

The culture conditions selected for the organotypic culture of human prostate that we developed from BPH tissues were based both on our own experience of organ culture [29] and on previous descriptions of prostate organ culture selected from the literature [30-32]. The culturing method of using well inserts was chosen for its ease of manipulation in the context of a high security laboratory, as opposed to other methods which required specific material [33]. The culture allowed for the preservation of the overall tissue architecture and the maintenance of all the prostatic cell types for 2.5 weeks ex vivo. Both normal and hyperplasic glands were observed before and after culturing. No increased proliferation of any specific cell type was observed after culturing. The constraint of working on explants of very small size in order to preserve tissue integrity did not allow for accurate quantification of immune cells throughout the culture. However, we unequivocally found that all the immune cell types identified before culturing were still present by day 17 .

We demonstrated here for the first time that human prostate from men with BPH is selectively infected by HIV-1 and releases infectious virions. Infected cells were mainly localized within the stroma and were rarely found within the epithelium, whether hyperplasic or normal. Their phenotype corresponded to either lymphocytes or macrophages, which, as previously evidenced by us and others, can be inserted within the epithelium [13,23,25-27]. Epithelial cells in the BPH prostate explants never stained positive for HIV receptors CD4, CXCR4 or CCR5 in immunohistochemistry. This confirms an in vitro study showing an absence of CD4, CXCR4 or CCR5 surface expression and the lack of productive infection by either
$\mathrm{R} 5$ or $\mathrm{X} 4$ virus strains of epithelial cells isolated from normal prostates [34]. Thus, unlike the renal epithelium that supports HIV replication in vivo [35], the prostatic epithelium does not constitute a site of active HIV infection.

The most efficiently and consistently replicating HIV-1 strain in prostate tissues was the prototypic $\mathrm{R}_{\mathrm{SF} 162}$. Prostate cultures were also susceptible to infection by a dual tropic primary isolate; albeit replication of the $\mathrm{R} 5 \mathrm{X} 4$ virus was much lower than the R5 strain (which could reflect the lower titre of R5X4 viral stock) and was variable depending on the patients. As assessed by RT activity measurement, infected cells were readily detected in situ and the viral particles recovered from infected prostate supernatants were able to subsequently infect PBMCs. In contrast, despite a higher titre of viral stock, $\mathrm{X}_{\text {IIIB }}$ spread in the prostate tissue was somewhat inefficient. This was demonstrated by the absence (or the very low level) of RT activity in infected culture supernatants after 17 days of culture, the scarce detection of infected cells in the tissues, and the fact that supernatants of prostate explants exposed to X4 were rarely able to induce infection of PBMCs. In addition, whilst in the prostate explants infected with R5 $5_{\text {SF162 }}$ HIV-1 DNA rose significantly from day 7 onwards, a delayed and much lower increase was observed within the explants exposed to $\mathrm{X} 4_{\mathrm{IIIB}}$. A longer duration of prostate culture may have allowed for a rise in $\mathrm{X} 4$ production, as suggested by the increase in $\mathrm{X} 4 \mathrm{DNA}$ towards the end of the culture period; however, since the prostate explant morphologies started to be disrupted after 17 days, the culture was not carried out any further. A similarly favoured replication of R5 over X4 strains has been described in foreskin, cervical, skin epidermal and fetal thymus explants [36-39]. In contrast, whilst rectosigmoid explants supported efficient replication by both R5 and X4 strains, tonsil explants, which displayed low numbers of CCR5+ cells, were less efficiently infected by R5 strains [40]. In foreskin, a predominance of CCR5 over CXCR4 expression by the tissue immune cells was observed, and this could explain the X4 restriction [36]. In our system, CXCR4 was readily detected and, in fact, CXCR4+ cells outnumbered CCR5+ cells. Although differences in antibody sensitivities may have led to an underestimation of CCR $5+$ cells, the restriction in $\mathrm{X} 4$ replication cannot be inferred as emerging from a lack of co-receptor expression. However, we cannot rule out that CXCR4+ cells in the prostate are mainly inactivated/naive CD4+T cells and/or CD8+T lymphocytes, both refractory to productive infection. Another hypothesis is that the cytokine environment of the prostate tissue restricts CXCR4-viral entry and/or spread. Thus, a high expression of the CXCR4 ligand CXCL12 (SDF-1) could impair X4 infection of prostate tissue, as previously described for the female genital mucosa $[41,42]$. However, the fact that viral DNA accumulation in prostate explants was similar for R $5_{\text {SF162 }}$ 

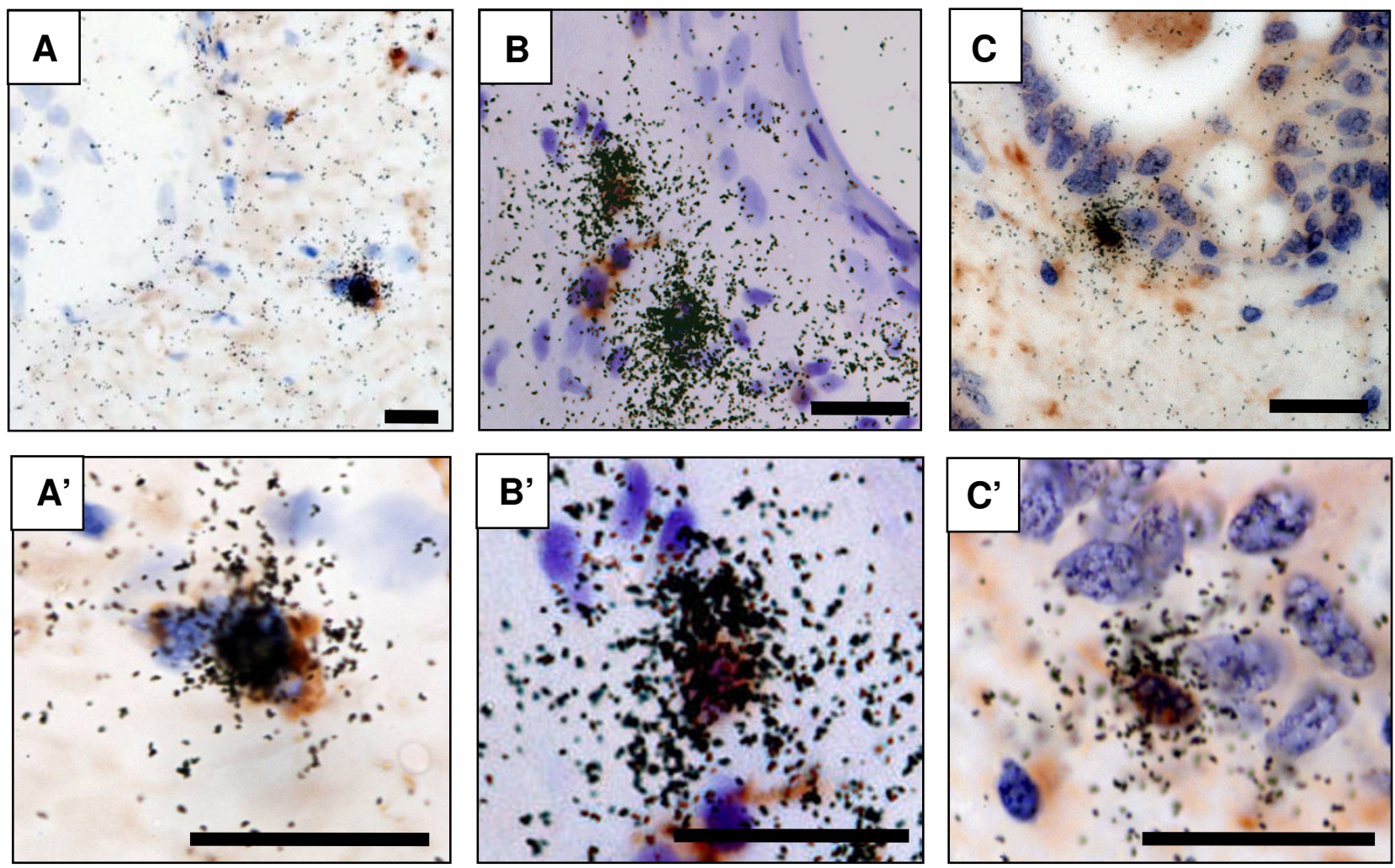

\section{Figure 5}

Localization and characterization of HIV-I RNA positive cells in the human prostate infected ex vivo. Localization of HIV RNA+ cells (black silver grains) in prostate explants exposed for 17 days to $\mathrm{R} 5_{\mathrm{SF} 162}(\mathrm{~A}, \mathrm{C})$ or $\mathrm{R} 5 \mathrm{X} 4_{92 \mathrm{US723}}$ (B) using in situ hybridization for HIV-I gag. Combined ISH with immunostaining for cell markers was used to assess co-localization of HIV RNA+ cells with either CD68 (A) or CD3 (B, C). A'-C' correspond to higher magnification of A-C showing cells colabelled for HIV RNA (black silver grains) and cell marker (brown cells). Scale bars $=20 \mu \mathrm{m}$.

and $\mathrm{X} 4_{\text {IIIB }}$ up to 7 days post-infection indicated that both strains entered target cells and retrotranscribed their RNA genome following virus exposure of prostate explants. Afterwards, only R5 efficiently propagated in the explants, whilst a much more modest rise in DNA was observed for $\mathrm{X} 4_{\text {IIIв }}$ after 17 days. This suggests that the limited X4 spread in prostate tissue is not due to an entry inhibition but rather resulted from either a slower replication kinetic or a more restricted number of cells that supported efficient replication following entry. In cervical explants, a post-entry block due to the non-activated status of T lymphocytes was described for lab-adapted X4 and primary isolates of $\mathrm{X} 4, \mathrm{R} 5 \mathrm{X} 4$, or R5. This block was compensated for in the prototypic $\mathrm{R} 5_{\mathrm{BaL}}$ strain by its efficient spreading in macrophages, while infecting only a few T lymphocytes $[37,43]$. Although the prototypic $\mathrm{R} 5_{\mathrm{SF} 162}$ strain used in our study can also efficiently spread in macrophages [44], the fact that the main infected cell type for both R5 and R5X4 was $T$ lymphocytes, indicated that the difference between R5/R5X4 and X4 strains was not due to exclusive replica- tion of the formers in macrophages, a cell type that $\mathrm{X} 4$ strains cannot productively infect [45]. One hypothesis is that the limited replication of $\mathrm{X} 4_{\text {ІШв }}$ is due to a sub-optimal level of activation of its target cells. Thus, sub-optimally stimulated CD4+T cells have been shown to only support the early steps of X4 viral replication. Whilst X4 replication in lymphocytes is a function of the time interval from mitogenic stimulation, R5 viruses require less stringent conditions of T-cell activation and are able to replicate in all subsets of sub-optimally activated $\mathrm{T}$ lymphocytes [46]. Since inflammatory infiltrates of BPH prostate tissues are mainly constituted of chronically activated CD4+ T cells, the activation status of those cells (i.e chronically rather than acutely activated) may allow efficient R5, but no X4, replication.

\section{Conclusion}

Our results demonstrated that the prostate is a site of R5 virus replication through the infection of the immune cells present in the tissue. The less efficient spread of HIV- 
$1 \mathrm{X} 4$ virus observed in the prostate explants could contribute to the preferential sexual transmission of HIV-1 R5 strains. Whether restricted $\mathrm{X} 4$ replication occurs in the prostate of HIV patients awaits further investigations, since different conditions such as the level of immune cell activation and the cytokine environment may modify X4 virus replication in the prostate in vivo.

\section{Competing interests}

The authors declare that they have no competing interests.

\section{Authors' contributions}

ALT, APS, HD, NRL, LH performed the experiments; NRL, AR, BJ contributed reagents/materials/analysis tools; ALT, APS, HD, NLR, AR, ND analyzed the data; ND conceived and designed the experiments.

\section{Acknowledgements}

We thank Christine Monfort for statistical analysis.

Sources of support - ANRS, Région Bretagne, Inserm - ALT was supported by Organon and ANRS stipends, H.D. were supported by ANRS and Région Bretagne.

\section{References}

I. Dejucq-Rainsford N, Jégou B: Viruses in semen and male genital tissues: consequences for the reproductive system and therapeutic perspectives. Current Pharmaceutical Design 2004, 1 0:557-575.

2. Zhang H, Dornadula G, Beumont M, Livornese LJ, Van Uitert B, Henning K, Pomerantz RJ: Human immunodeficiency virus type I in the semen of men receiving highly active antiretroviral therapy. N Engl J Med 1998, 339:1803-1809.

3. Kiessling AA, Fitzgerald LM, Zhang D, Chhay H, Brettler D, Eyre RC, Steinberg J, McGowan K, Byrn RA: Human immunodeficiency virus in semen arises from a genetically distinct virus reservoir. AIDS Res Hum Retroviruses 1998, I4:S33-S4I.

4. Mayer KH, Boswell S, Goldstein R, Lo W, Xu C, Tucker L, DePas quale MP, D'Aquila R, Anderson DJ: Persistence of human immunodeficiency virus in semen after adding indinavir to combination antiretroviral therapy. Clin Infect Dis 1999, 28: $1252-1259$

5. Lafeuillade A, Solas C, Halfon P, Chadapaud S, Hittinger G, Lacarelle $B$ : Differences in the detection of three HIV-I protease inhibitors in non-blood compartments: Clinical correlations. HIV Clin Trials 2002, 3:27-35.

6. Solas C, Lafeuillade A, Halfon P, Chadapaud S, Hittinger G, Lacarelle B: Discrepancies between Protease Inhibitor Concentrations and Viral Load in Reservoirs and Sanctuary Sites in Human Immunodeficiency Virus-Infected Patients. Antimicrob Agents Chemother 2003, 47:238-243.

7. Bujan L, Daudin M, Matsuda T, Righi L, Thauvin L, Berges L, Izopet J Berrebi A, Massip P, Pasquier C: Factors of intermittent HIV-I excretion in semen and efficiency of sperm processing in obtaining spermatozoa without HIV-I genomes. Aids 2004, I 8:757-766.

8. Anderson DJ, Politch JA, Martinez A, Van Voorhis BJ, Padian NS, O'Brien TR: White blood cells and HIV-I in semen from vasectomised seropositive men. Lancet 1991, 338:573-574.

9. Schwartz GG: Vasectomy and human immunodeficiency virus of mice and men. Fertil Steril 199I, 55:650-65I.

10. Krieger JN, Nirapathpongporn A, Chaiyaporn M, Peterson G, Nikolaeva I, Akridge R, Ross SO, Coombs RW: Vasectomy and human immunodeficiency virus type I in semen. J Urol 1998 I 59:820-825.

II. Paranjpe S, Craigo J, Patterson B, Ding M, Barroso P, Harrison L Montelaro R, Gupta P: Subcompartmentalization of HIV-I Quasispecies between Seminal Cells and Seminal Plasma
Indicates Their Origin in Distinct Genital Tissues. AIDS Res Hum Retroviruses 2002, I 8: I 27|-1280.

12. De Marzo AM, Platz EA, Sutcliffe S, Xu J, Gronberg H, Drake CG, Nakai Y, Isaacs WB, Nelson WG: Inflammation in prostate carcinogenesis. Nat Rev Cancer 2007, 7:256-269.

13. Le Tortorec A, Le Grand R, Denis H, Satie AP, Mannioui K, Roques P, Maillard A, Daniels S, Jegou B, Dejucq-Rainsford N: Infection of semen-producing organs by SIV during the acute and chronic stages of the disease. PLOS ONE 2008, 3: el 792.

14. Smith DM, Kingery JD, Wong JK, Ignacio CC, Richman DD, Little S]: The prostate as a reservoir for HIV-I. Aids 2004, I 8: I600-I602.

15. Coombs RW, Lockhart D, Ross SO, Deutsch L, Dragavon J, Diem K Hooton TM, Collier AC, Corey L, Krieger JN: Lower genitourinary tract sources of seminal HIV. J Acquir Immune Defic Syndr 2006, 41:430-438.

16. Roulet V, Satie AP, Ruffault A, Le Tortorec A, Denis H, Guist'hau O, Patard J, Rioux-Leclerq N, Gicquel J, Jegou B, Dejucq-Rainsford N: Susceptibility of human testis to human immunodeficiency virus-I infection in situ and in vitro. Am J Pathol 2006, 169:2094-2103.

17. Desire N, Dehee A, Schneider V, Jacomet C, Goujon C, Girard PM, Rozenbaum W, Nicolas JC: Quantification of human immunodeficiency virus type I proviral load by a TaqMan real-time PCR assay. J Clin Microbiol 200 I, 39: I303-I310.

18. Da Silva M, Shevchuk MM, Cronin WJ, Armenakas NA, Tannenbaum $M$, Fracchia JA, loachim HL: Detection of HIV related protein in testes and prostates of patients with AIDS. Am J Clin Pathol 1990, 93:196-201.

19. Ablin RJ: HIV-related protein in the prostate: a possible reservoir of virus. Am J Clin Pathol I99I, 95:759-760.

20. Pudney J, Anderson D: Orchitis and human immunodeficiency virus type $I$ infected cells in reproductive tissues from men with the acquired immune deficiency syndrome. Am J Pathol 1991, 139:149-160.

21. Kramer G, Mitteregger D, Marberger M: Is benign prostatic hyperplasia (BPH) an immune inflammatory disease? Eur Urol 2007, 51:1202-1216.

22. McClinton S, Miller ID, Eremin O: An immunohistochemical characterisation of the inflammatory cell infiltrate in benign and malignant prostatic disease. Br J Cancer 1990, 6 I:400-403.

23. Theyer G, Kramer G, Assmann I, Sherwood E, Preinfalk W, Marberger M, Zechner O, Steiner GE: Phenotypic characterization of infiltrating leukocytes in benign prostatic hyperplasia. Lab Invest 1992, 66:96-107.

24. Steiner G, Gessl A, Kramer G, Schollhammer A, Forster O, Marberger $M$ : Phenotype and function of peripheral and prostatic lymphocytes in patients with benign prostatic hyperplasia. I Urol 1994, I 5 I:480-484.

25. El-Dermiry M, Hargreave T, Busuttil A, James K, Ritchie A, Chrisholm $\mathrm{G}$ : Lymphocyte subpopulations in the male genital tract. $\mathrm{Br}$ J Urol 1985, 57:769.

26. Bostwick DG, de la Roza G, Dundore P, Corica FA, Iczkowski KA: Intraepithelial and stromal lymphocytes in the normal human prostate. Prostate 2003, 55:187-193

27. Anderson DJ, Pudney J: Human male genital tract immunity and experimental models. In Mucosal Immunology Volume 2. 3rd edition. Edited by: Mestecky J, Lamm M, Strober W, Bienenstock J, McGhee J, Mayer L. New-York, NY: Elsevier Academic Press; 2005:1647-1659.

28. Nickel JC, True LD, Krieger JN, Berger RE, Boag AH, Young ID: Consensus development of a histopathological classification system for chronic prostatic inflammation. BJU Int 200I, 87:797-805.

29. Roulet V, Denis H, Staub C, Le Tortorec A, Delaleu B, Satie AP, Patard J, Jegou B, Dejucq-Rainsford N: Human testis in organotypic culture: application for basic or clinical research. Hum Reprod 2006, 21:1564-1575.

30. Papini S, Rosellini A, Campani D, DeMatteis A, Selli C, Revoltella RP: Selective growth of epithelial basal cells from human prostate in a three-dimensional organ culture. Prostate 2004, 59:383-392

31. Varani J, Dame MK, Wojno K, Schuger L, Johnson KJ: Characteristics of nonmalignant and malignant human prostate in organ culture. Lab Invest 1999, 79:723-731.

32. Parrish AR, Sallam K, Nyman DW, Orozco J, Cress AE, Dalkin BL, Nagle RB, Gandolfi AJ: Culturing precision-cut human prostate 
slices as an in vitro model of prostate pathobiology. Cell Biol Toxicol 2002, I 8:205-219.

33. Margolis L, Hatfill S, Chuaqui R, Vocke C, Emmert-Buck M, Linehan WM, Duray PH: Long term organ culture of human prostate tissue in a NASA-designed rotating wall bioreactor. J Urol 1999, 161:290-297.

34. Dezzutti CS, Guenthner PC, Cummins JE Jr, Cabrera T, Marshall JH, Dillberger A, Lal RB: Cervical and prostate primary epithelial cells are not productively infected but sequester human immunodeficiency virus type I. J Infect Dis 200I, I 83: I 204-I2I3.

35. Bruggeman LA, Ross MD, Tanji N, Cara A, Dikman S, Gordon RE, Burns GC, D'Agati VD, Winston JA, Klotman ME, Klotman PE: Renal epithelium is a previously unrecognized site of HIV-I infection. J Am Soc Nephrol 2000, I I:2079-2087.

36. Patterson BK, Landay A, Siegel JN, Flener Z, Pessis D, Chaviano A Bailey RC: Susceptibility to human immunodeficiency virus- $I$ infection of human foreskin and cervical tissue grown in explant culture. Am J Pathol 2002, 161:867-873.

37. Greenhead P, Hayes P, Watts PS, Laing KG, Griffin GE, Shattock RJ: Parameters of human immunodeficiency virus infection of human cervical tissue and inhibition by vaginal virucides. J Virol 2000, 74:5577-5586.

38. Reece JC, Handley AJ, Anstee EJ, Morrison WA, Crowe SM, Cameron PU: HIV-I selection by epidermal dendritic cells during transmission across human skin. J Exp Med 1998, 187:1623-1631.

39. Rosenzweig M, Bunting EM, Damico RL, Clark DP, Gaulton GN: Human neonatal thymic organ culture: an ex vivo model of thymocyte ontogeny and HIV-I infection. Pathobiology 1994, 62:245-25I.

40. Grivel JC, Elliott J, Lisco A, Biancotto A, Condack C, Shattock RJ, McGowan I, Margolis L, Anton P: HIV-I pathogenesis differs in rectosigmoid and tonsillar tissues infected ex vivo with CCR5- and CXCR4-tropic HIV-I. Aids 2007, 21:1263-I272.

4I. Zaitseva M, Blauvelt A, Lee S, Lapham CK, Klaus-Kovtun V, Mostowski H, Manischewitz J, Golding H: Expression and function of CCR5 and CXCR4 on human Langerhans cells and macrophages: implications for HIV primary infection. Nat Med 1997, 3:1369-1375.

42. Agace WW, Amara A, Roberts AI, Pablos JL, Thelen S, Uguccioni M, Li XY, Marsal J, Arenzana-Seisdedos F, Delaunay T, et al.: Constitutive expression of stromal derived factor- $I$ by mucosal epithelia and its role in HIV transmission and propagation. Curr Biol 2000, 10:325-328.

43. Hladik F, Lentz G, Akridge RE, Peterson G, Kelley H, McElroy A, McElrath MJ: Dendritic cell-T-cell interactions support coreceptor-independent human immunodeficiency virus type I transmission in the human genital tract. J Virol 1999, 73:5833-5842

44. Stamatatos L, Wiskerchen M, Cheng-Mayer C: Effect of major deletions in the VI and V2 loops of a macrophage-tropic HIV type I isolate on viral envelope structure, cell entry, and replication. AIDS Res Hum Retroviruses 1998, 14: I I29-1 I39.

45. Schmidtmayerova $H$, Alfano $M$, Nuovo G, Bukrinsky M: Human immunodeficiency virus type I T-lymphotropic strains enter macrophages via a CD4- and CXCR4-mediated pathway: replication is restricted at a postentry level. J Virol 1998 72:4633-4642

46. Vicenzi E, Bordignon PP, Biswas P, Brambilla A, Bovolenta C, Cota M, Sinigaglia F, Poli G: Envelope-dependent restriction of human immunodeficiency virus type I spreading in CD4(+) T lymphocytes: $R 5$ but not $X 4$ viruses replicate in the absence of T-cell receptor restimulation. J Virol 1999, 73:75I5-7523.

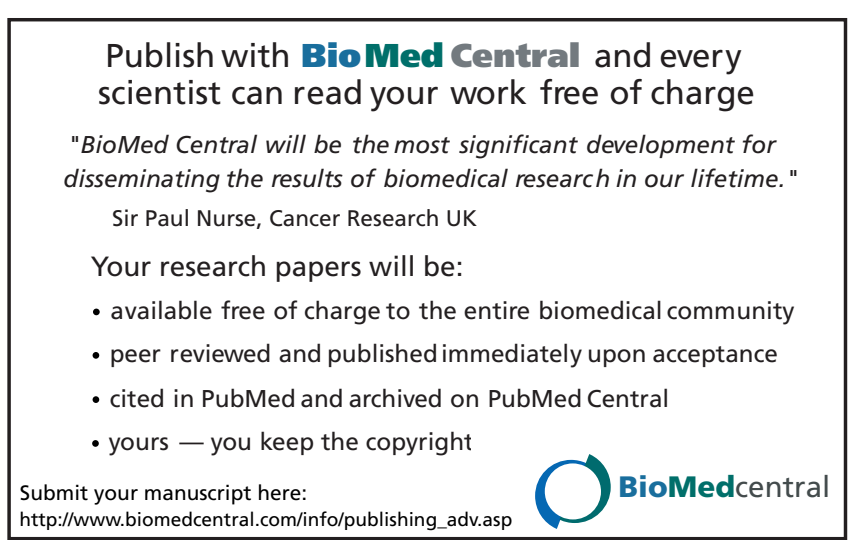

